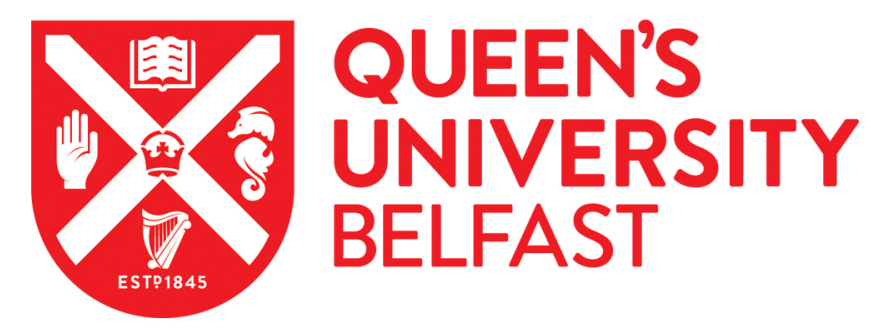

\title{
Cytotoxicity of Mechanochemically Prepared Cu(II) Complexes
}

McCalmont, A. S., Ruiz Estrada, G. A., Lagunas, M. C., Al-Jamal, W. T., \& Crawford, D. (2020). Cytotoxicity of Mechanochemically Prepared Cu(II) Complexes. ACS Sustainable Chemistry \& Engineering.

https://doi.org/10.1021/acssuschemeng.0c04950

\section{Published in:}

ACS Sustainable Chemistry \& Engineering

\section{Document Version:}

Peer reviewed version

Queen's University Belfast - Research Portal:

Link to publication record in Queen's University Belfast Research Portal

\section{Publisher rights}

Copyright $\odot 2020$ American Chemical Society. This work is made available online in accordance with the publisher's policies. Please refer to any applicable terms of use of the publisher.

\section{General rights}

Copyright for the publications made accessible via the Queen's University Belfast Research Portal is retained by the author(s) and / or other copyright owners and it is a condition of accessing these publications that users recognise and abide by the legal requirements associated with these rights.

Take down policy

The Research Portal is Queen's institutional repository that provides access to Queen's research output. Every effort has been made to ensure that content in the Research Portal does not infringe any person's rights, or applicable UK laws. If you discover content in the Research Portal that you believe breaches copyright or violates any law, please contact openaccess@qub.ac.uk. 
This document is confidential and is proprietary to the American Chemical Society and its authors. Do not copy or disclose without written permission. If you have received this item in error, notify the sender and delete all copies.

\section{Cytotoxicity of Mechanochemically Prepared Cu(II) Complexes}

\begin{tabular}{|r|l|}
\hline Journal: & ACS Sustainable Chemistry \& Engineering \\
\hline Manuscript ID & Sc-2020-04950t.R1 \\
\hline Manuscript Type: & Article \\
\hline Complete List of Authors: & $\begin{array}{l}\text { McCalmont, Aaron; Queen's University Belfast, School of Chemistry and } \\
\text { Chemical Engineering } \\
\text { Ruiz, Amalia; Queen's University Belfast, } \\
\text { Lagunas, M. Cristina; Queen's University Belfast, School of Chemistry } \\
\text { Al-Jamal, Wafa; Queen's University of Belfast School of Pharmacy, } \\
\text { School of Pharmacy } \\
\text { Crawford, Deborah; University of Bradford Faculty of Life Sciences, } \\
\text { School of Chemistry and Biosciences }\end{array}$ \\
\hline
\end{tabular}

\section{SCHOLARONE \\ Manuscripts}




\section{Cytotoxicity of Mechanochemically Prepared $\mathrm{Cu}(\mathrm{II})$ \\ Complexes}

Aaron S. McCalmont, ${ }^{a}$ Amalia Ruiz, ${ }^{b}$ M. Cristina Lagunas, ${ }^{a}$ Wafa T. Al-JamaP and

Deborah E. Crawford ${ }^{*}$

a) School of Chemistry and Chemical Engineering, David Keir Building, Queen's University Belfast, 39 - 123 Stranmillis Road, Belfast, BT9 5AG.

b) School of Pharmacy, Queen's University Belfast, 97 Lisburn Road, Belfast, BT9 $7 \mathrm{BL}$

c) School of Chemistry and Biosciences, University of Bradford, Richmond Building, Richmond Road, Bradford, BD7 1DP. Email: D.Crawford@bradford.ac.uk 


\begin{abstract}
Despite evidence that mechanochemistry has the potential to be a revolutionary manufacturing technique, the Pharma industry is still reluctant to introduce these new technologies into their manufacturing processes. Therefore, it is now time to pioneer the implementation of mechanochemistry in industry, by analysing the bioactive and physicochemical properties of mechanochemical products. Herein, we report the mechanochemical synthesis of a $\mathrm{Cu}(\mathrm{II})$ metallodrug, that has been previously investigated in solution. Interestingly, we found that ball milling leads to the formation of a novel $\mathrm{Cu}(\mathrm{II})$ complex of octahedral geometry, whereas conventional synthesis resulted in a square-pyramidal complex. In addition, we report for the first time, the enhanced cytotoxicity of this $\mathrm{Cu}(\mathrm{II})$ metallodrug, towards ovarian cancer cell lines, as a result of its mechanochemical preparation.
\end{abstract}

KEYWORDS: Mechanochemistry • Metallodrugs - Active Pharmaceutical Ingredients (APIs) $・$ Cytotoxicity $•$ Green Chemistry

INTRODUCTION 
Significant advances have been made in the field of solvent-free synthesis, with IUPAC naming mechanochemistry as one of the top ten innovations that will change the world.[1] Many areas of inorganic, organic and material syntheses have been explored by ball milling in a mixer mill (Figure 1a). These include C-C bond formations,[2a,b] preparation of porous materials (e.g. Metal Organic Frameworks (MOFs))[3] and formation of

a)

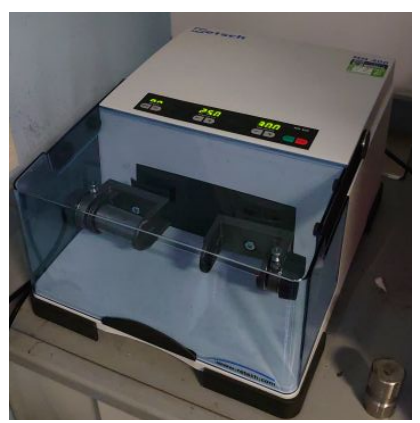

Mixer Ball Mill b)

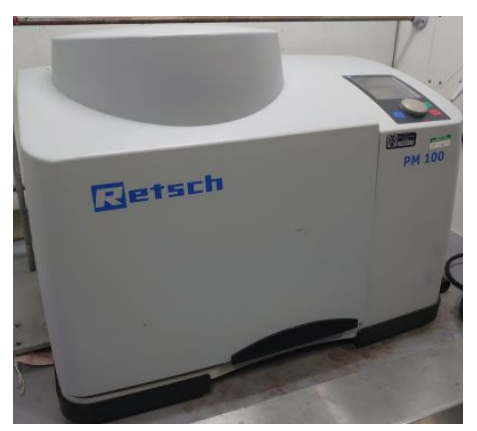

Planetary Ball Mill c)

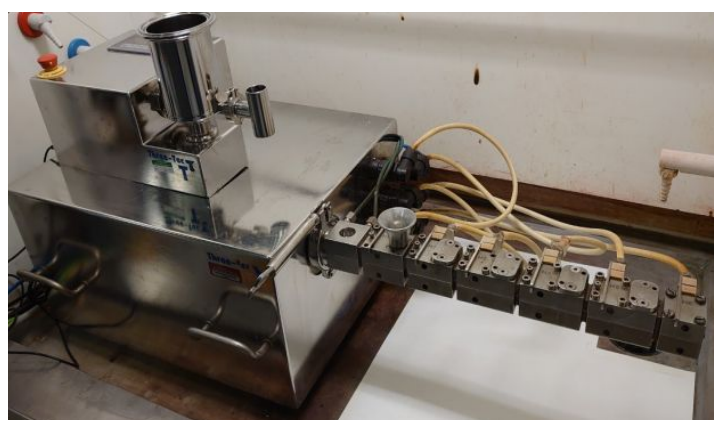

Twin-Screw Extruder

coordination compounds, as well as composite and alloy materials.[4] Mechanochemistry

provides a route to many known chemical transformations, but it has also led to the formation of products typically unobtainable via conventional methods.[5]

Figure 1. a) Mixer ball mill ( $<5 \mathrm{~g}$ scale), b) planetary ball mill ( $<500 \mathrm{~g}$ scale) and c) a twin-screw extruder $\left(\mathrm{kghr}^{-1}\right)$. 
As a result of growing interest into the field, scale-up has been an important topic, with many research groups utilising planetary mills to investigate this as a batch process

(Figure 1b).[6] In this context, we have demonstrated the continuous solvent-free synthesis of several organic and inorganic materials using Twin-Screw Extrusion (TSE),[7] a method already established in food production and in the formulation of Active Pharmaceutical Ingredients (APIs) (Figure 1c).[8] Employing a laboratory sized extruder gives us the opportunity to scale-up solvent-free synthesis to a $\mathrm{kghr}^{-1}$ scale, and with larger extruders available, further scale-up to tonhr-1 quantities is easily achievable.

One area of particular interest in mechanochemistry is the synthesis of APIs, and there are several examples in the literature of preparing these compounds by ball milling,[9] such as in the case of glibenclamide[10], and more recently by TSE, the synthesis of the hydrazone-based antibiotic, Nitrofurantoin,[11]. However, the Pharma industry are still hesitant about implementing mechanochemical synthesis into their manufacturing processes. One of the main reasons for this is that mechanochemistry is still a relatively 
novel topic, and most of the research over the last two decades has focused solely on the mechanochemical synthesis process, i.e. identifying reaction types that can be carried out without a solvent. There are, however, relatively few studies on how mechanochemically-prepared materials can be implemented in the real world, i.e. when they are used for their intended application. Until very recently, there were no reports yet on the biological activity of compounds obtained mechanochemically. However, Bantreil and Gaillard et al.[12] have recently published the synthesis of cytotoxic silver nheterocyclic carbenes by ball milling, wherein the final complexes demonstrated $I_{50}$ values as low as $21 \mathrm{nM}$, making them 256 times more potent than cisplatin.[12]

Due to the lack of knowledge on the activity of mechanochemically prepared APIs, before mechanochemical manufacture is implemented into the Pharma industry, it is vital that we understand and identify any differences in the physicochemical and pharmacokinetic properties of these products. Furthermore, APIs prescribed in a solid form, i.e. a tablet, need to be dissolved in the body to be effective. If the dissolution rates differ from that expected, this will affect parameters such as API half-life (time required for an API 
concentration in the body to be reduced by one half).[13] This can also be extended to intravenous solutions and various drug delivery platforms, e.g. skin patches,[14] as differences in the pharmacokinetic factors can affect how quickly an API is absorbed by the patient's plasma and then eliminated.[15]

The use of metals for pain relief and the effective management or treatment of diseases and infections is well reported.[16] Furthermore, coordination of a metal to an already known API has been seen to increase the dissolution rates of the latter, which may have an impact in overcoming drug resistance.[17] This has been particularly true with regards to the coordination of $\mathrm{Cu}(\mathrm{II})$ to various Non-Steroidal Anti-Inflammatory Drugs (NSAIDs). Enhanced potency is achieved via the higher dissolution rates of the copper complex compared to the free ligand, as well as possible $\mathrm{Cu}(\mathrm{II})-\mathrm{Cu}(\mathrm{I})$ redox cycling processes occurring.[18] 
Currently, the only $\mathrm{Cu}(\mathrm{II})-\mathrm{NSAID}$ approved by the Medical and Healthcare products Regulatory Agency (MHRA) is a $\mathrm{Cu}(\mathrm{II})$ dimer of indomethacin,[19a] which is utilised for the treatment of inflammation and arthritis in domestic animals.[19b] However, a number of $\mathrm{Cu}(\mathrm{II})$-NSAIDs have been shown to exhibit promising chemosuppressive and chemopreventive properties and therefore deserve further investigation. For example, in vitro studies carried out by Cini et al.[20,21] demonstrated high anti-proliferative activity of $\left[\mathrm{Cu}(\mathrm{HPir})_{2}(\mathrm{DMF})_{2}\right]$ (where $\mathrm{H}_{2} \mathrm{Pir}=$ piroxicam, Figure 2) against Small Cell Lung $(\mathrm{SCL})$, Non-Small Cell Lung (NSCL), ovarian and melanoma tumours.[21] This advantageous behaviour is proposed to arise from $\mathrm{Cu}(\mathrm{II})-\mathrm{NSAIDs}$ directly intercalating with ctDNA, disrupting the DNA backbone, and thus reducing cell viability, as confirmed by Circular Dichroism (CD) spectroscopy.[22] In addition, Alexandrova et al.[23] considered the antiproliferative effects of metal complexes with meloxicam $\left(\mathrm{H}_{2} \mathrm{Mel}\right.$, a NSAID) acting as a ligand, and showed that $\left[\mathrm{M}(\mathrm{HMel})_{2}\left(\mathrm{H}_{2} \mathrm{O}\right)_{2}\right]$ (where $\left.\mathrm{M}=\mathrm{Cu}, \mathrm{Zn}, \mathrm{Co}, \mathrm{Ni}\right)$ exhibited improved cytotoxic effects compared to uncoordinated $\mathrm{H}_{2} \mathrm{Mel}$. 


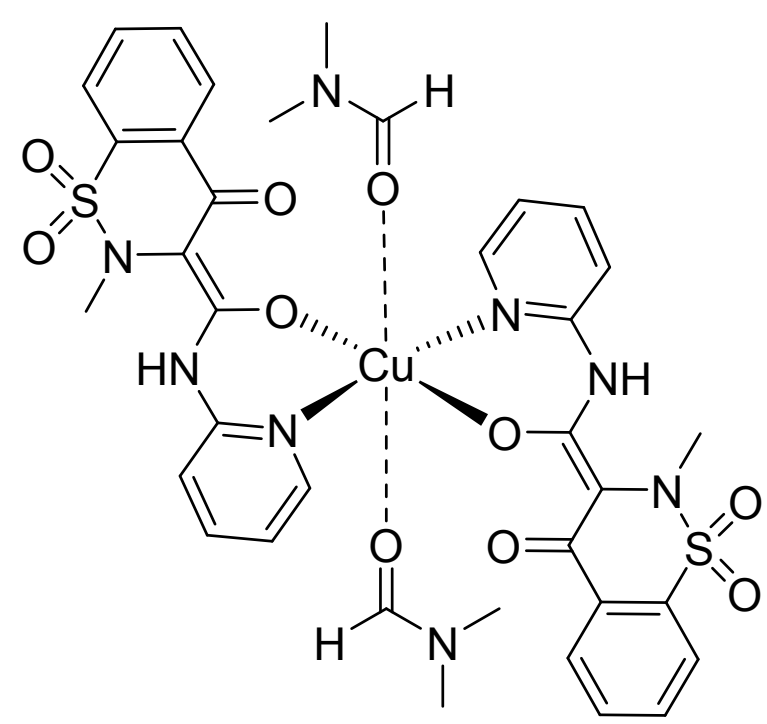

Figure 2. Structure of $\left[\mathrm{Cu}(\mathrm{HPir})_{2}(\mathrm{DMF})_{2}\right]$, as reported by Cini et al..[20]

Described herein is the solvent-free preparation of potential chemotherapeutic agents.

We wish to demonstrate that APIs prepared under solvent-free conditions exhibit the same cytotoxic behaviour as their conventionally prepared counterparts. We believe that this work is the next logical and important step in demonstrating that mechanochemical synthesis has excellent potential for API manufacture. 


\section{RESULTS AND DISCUSSION}

Considering the relevance of $\mathrm{Cu}(\mathrm{II})$-NSAIDs in cancer research, we focused our investigations on the ball mill synthesis of $\mathrm{Cu}(\mathrm{II})$ meloxicam complexes, $\left[\mathrm{Cu}(\mathrm{HMel})_{2}(\mathrm{~S})_{x}\right]$ (where $S=D M F$ or an alternative coordinating ligand, and $x=1$ or 2 ). In vitro studies have shown that the mechanochemically prepared derivates exhibit similar or enhanced cancer cell death within $48 \mathrm{hrs,}$ compared to the conventionally prepared compound, of which the solvent-based synthesis and cytotoxicity has been reported previously.[21] This was desirable as it offered a basis upon which our cytotoxicity data could be compared to. Although these $\mathrm{Cu}(\mathrm{II})$ complexes are not yet available on the market as chemotherapeutic agents, this work shows for the first time that solvent-free manufacturing processes can be established without loss of biological activity.

The solvent-based synthesis of $\left[\mathrm{Cu}(\mathrm{HMel})_{2}(\mathrm{DMF})\right]$ was carried out as reported by Cini et al.,[21] in which $\left(\mathrm{Cu}(\mathrm{OAc})_{2} \cdot \mathrm{H}_{2} \mathrm{O}\right)$ was refluxed with commercially sourced $\mathrm{H}_{2} \mathrm{Mel}$ in EtOH for $2 \mathrm{hrs,}$ followed by recrystallisation from DMF, resulting in the formation of the hydrated 
complex $\left(\left[\mathrm{Cu}(\mathrm{HMel})_{2}(\mathrm{DMF})\right] \cdot 0.25 \mathrm{H}_{2} \mathrm{O}\right)$ (Figure 3).[21] The green product obtained was characterised by Infrared (IR) spectroscopy and Powder X-ray Diffraction (PXRD), and the results were fully consistent with those reported for $\left(\left[\mathrm{Cu}(\mathrm{HMel})_{2}(\mathrm{DMF})\right] \cdot 0.25 \mathrm{H}_{2} \mathrm{O}\right)$, including a good match between the PXRD pattern of the product and the simulated pattern from crystallographic data (see ESI, Figure S1(b)).[21] Single Crystal X-ray Diffraction (SXRD) studies have shown that one DMF molecule coordinates apically to the $\mathrm{Cu}(\mathrm{II})$ centre, adopting a square-pyramidal geometry instead of the more common octahedral shape.[21] This has been attributed to i) steric hindrance and ii) the formation<smiles></smiles>
so that a solvent molecule cannot coordinate to the adjacent apical \begin{tabular}{ll|l} 
& i) $\mathrm{EtOH} / \Delta / 2 \mathrm{~h}$ & $-2 \mathrm{AcOH}$ \\
coordination site.[24] & ii) $\mathrm{DMF}$ & $-\mathrm{H}_{2} \mathrm{O}$
\end{tabular}

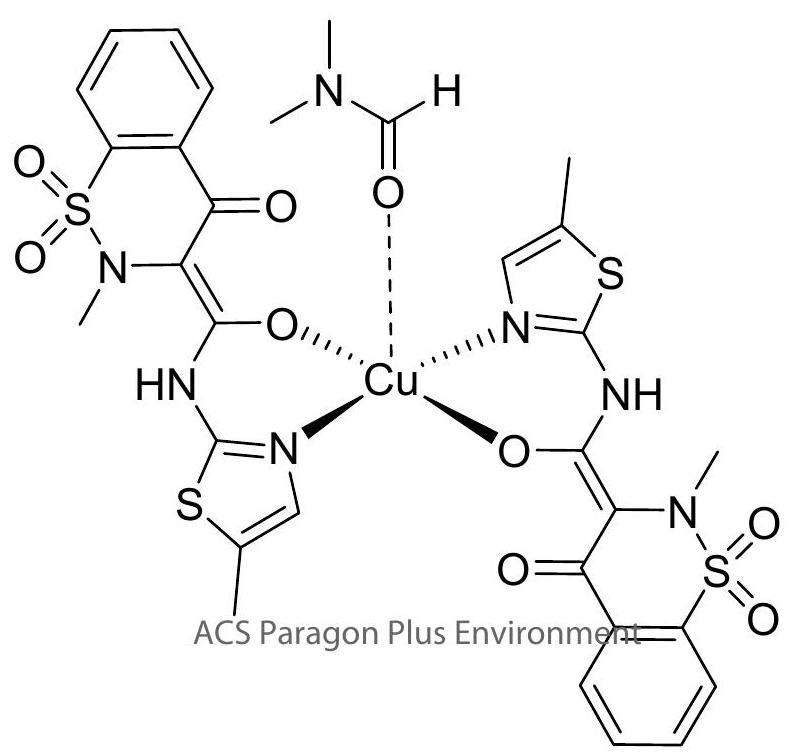


Figure 3. Conventional synthesis of $\left(\left[\mathrm{Cu}(\mathrm{HMel})_{2}(\mathrm{DMF})\right] \cdot 0.25 \mathrm{H}_{2} \mathrm{O}\right)$ carried out in $\mathrm{EtOH}$, followed by recrystallisation from DMF, as reported by Cini et al..[21] 
Ball milling between $\left(\mathrm{Cu}(\mathrm{OAc})_{2} \cdot \mathrm{H}_{2} \mathrm{O}\right)$ and 2 mol. eq. of $\mathrm{H}_{2} \mathrm{Mel}$ was initially attempted under neat conditions but was unsuccessful, most likely due to the absence of coordinating DMF. Therefore, the reaction was repeated with $1 \mathrm{~mol}$. eq. of DMF, but this resulted in a black, viscous material that could not be characterised by PXRD. Since the solvent-based synthesis employs both EtOH and DMF, a ca. 1:1.1 mol eq. EtOH:DMF mixture was used in the ball mill reaction, with PXRD indicating that a partial reaction had taken place.

Subsequent to this, the parameters required to drive the reaction to completion were investigated, with ball mill frequency $(10-25 \mathrm{~Hz})$, milling time $(15-60 \mathrm{mins})$ and the amount of added solvent varied. PXRD was used to monitor the outcome of each reaction. The variable frequency experiments $(1 \mathrm{hr}, 1: 1.1 \mathrm{~mol}$. eq. EtOH:DMF) showed that at frequencies over $15 \mathrm{~Hz}$ there was loss of crystallinity in the final product. Additionally, in all cases the PXRD patterns contained sharp diffraction peaks at $2 \theta$ positions of $c a .38 .4^{\circ}$ and ca. $44.7^{\circ}$, attributed to residual quantities of $\left(\mathrm{Cu}(\mathrm{OAc})_{2} \cdot \mathrm{H}_{2} \mathrm{O}\right)$ (see ESI, Figures S3 - 
S6). However, by increasing the amount of EtOH:DMF to 2:2.2 mol. eq., a complete conversion to product was obtainable at a frequency of $15 \mathrm{~Hz}$ within 15 mins (Figure 4a).

The elemental (CHNS) analysis of the ball milled product was close to that expected for $\left(\left[\mathrm{Cu}(\mathrm{HMel})_{2}(\mathrm{DMF})\right] \cdot 0.25 \mathrm{H}_{2} \mathrm{O}\right)$ (see ESI), and its IR spectrum matched that of the conventionally synthesised complex, although the IR bands of the ball mill product were generally broader; for example, the $\mathrm{v}(\mathrm{CO})$ stretching band of coordinated DMF (ca. 1680 $\mathrm{cm}^{-1}$ ) appeared as a shoulder on the broad band present at ca. $1570 \mathrm{~cm}^{-1}$ (see ESI, Figure S11). However, comparison of the PXRD pattern for the ball mill product with both the simulated[21] and solution PXRD patterns, did show some differences (Figure 4b). In particular, an additional diffraction peak at a $2 \theta$ value of $c a .26^{\circ}$ was present in the pattern of the ball

a)

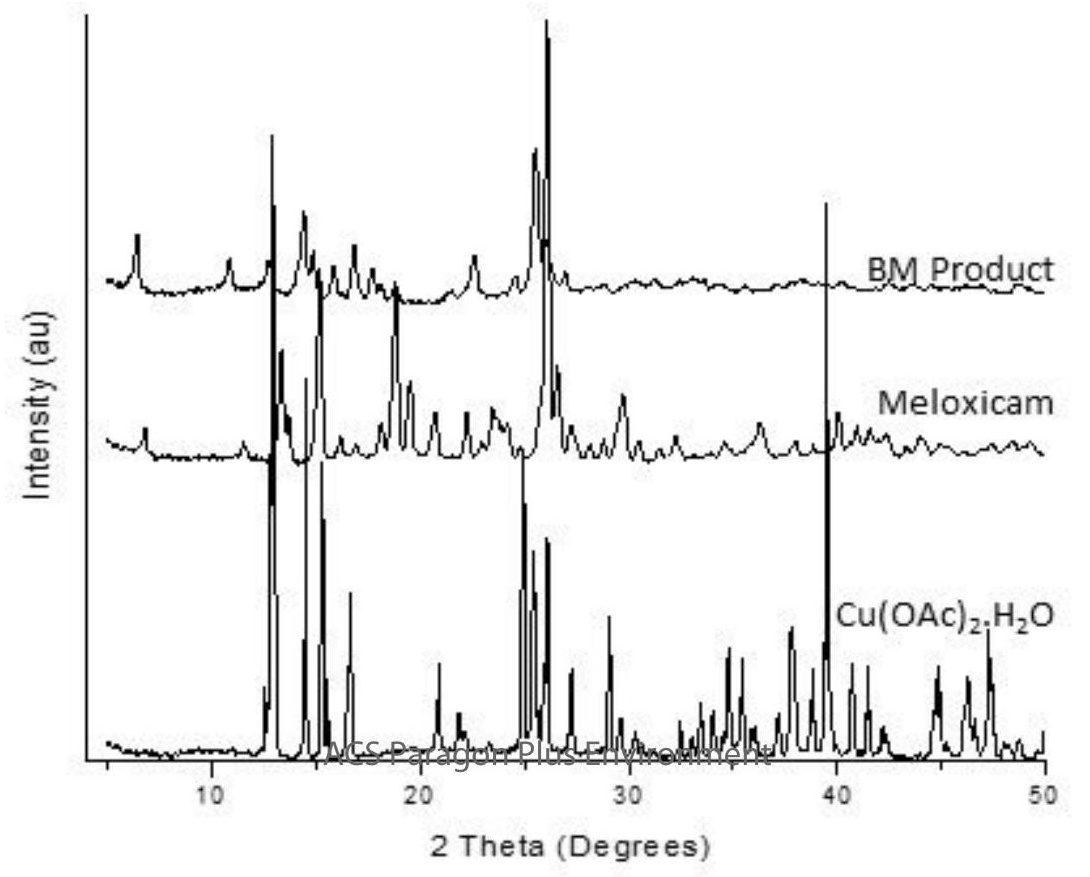

mill product. 
b)

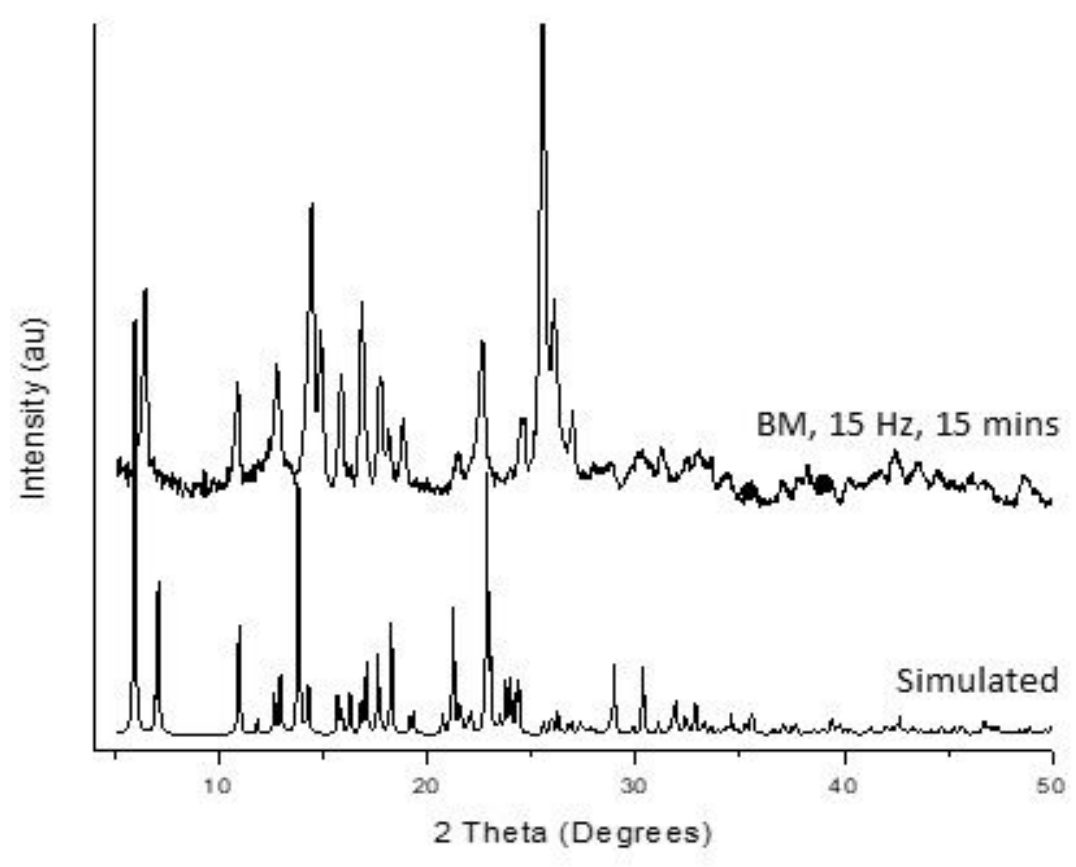

Figure 4. PXRD pattern of the product obtained by ball milling $\left(\mathrm{Cu}(\mathrm{OAc})_{2} . \mathrm{H} 2 \mathrm{O}\right)$ and $\mathrm{H}_{2} \mathrm{Mel}$ (1:2), at $15 \mathrm{~Hz}$ for 15 mins, in the presence EtOH:DMF (2:2.2), compared with (a) the 
PXRD patterns of starting materials, and (b) the simulated pattern for $\left(\left[\mathrm{Cu}(\mathrm{HMel})_{2}(\mathrm{DMF})\right] \cdot 0.25 \mathrm{H}_{2} \mathrm{O}\right)(\mathrm{CCDC}: 654174) \cdot[21]$ (BM = Ball Mill)

The geometry of the ball mill product was then investigated as the source of differing PXRD patterns. As 2.2 mol. eq. of DMF was added to the reactions, it is feasible that DMF coordinates to both axial positions. Unfortunately, crystals suitable for SXRD were not obtained, which could have confirmed the geometry of the ball mill product.

IR spectroscopy did not reveal any information regarding the compound's geometry, as the spectrum reported for the solution-synthesised compound and that of the ball mill product were very similar, as noted above. The found CHNS composition indicates the presence of only one DMF molecule per $\mathrm{Cu}(\mathrm{II})$ atom, but the product had to be dried overnight in order to remove excess solvent prior to submitting the sample for elemental analysis. In these conditions, it is possible that some of the DMF was also removed. 
PXRD was therefore our main route to hypothesising the final geometry of the ball mill product. Chen et al.[25] report formation of two different $\mathrm{Cu}(\mathrm{II})$ coordination complexes with the API, topiroxostat (ptpc). The authors prepared both an octahedral, $\left(\mathrm{Cu}(\mathrm{ptpc})_{2}\left(\mathrm{NO}_{3}\right)_{2}(\mathrm{DEF})_{2}\right) \quad(\mathrm{DEF}=$ diethylformamide $)$, and a square-pyramidal, $\left(\left[\mathrm{Cu}(\mathrm{ptpc})_{2}\left(\mathrm{NO}_{3}\right)(\mathrm{DMF})_{2}\right] \cdot \mathrm{NO}_{3}\right)$, complex; obtaining the different geometries by changing the alkyl group in the dialkylformamide solvent.[25] SXRD was used to determine the geometry however, as this was unavailable to us, we considered the differences in the diffraction patterns reported by Chen et al.,[25] namely in the $2 \theta$ range of $5-10^{\circ}$ and at ca. $28^{\circ}$, and compared them to those we were observing. With regards to the former, diffraction occurs at different angles dependent on geometry, i.e. the octahedral complex diffracts at a $2 \theta$ of $c a .8 .0^{\circ}$ and $c a .7 .2^{\circ}$ for the square-pyramidal geometry. This is also observed herein, with the simulated pattern showing a diffraction peak at a $2 \theta$ value of ca. $5.6^{\circ}[21]$ compared to the ball mill product diffraction peak at a $2 \theta$ value of $c a \cdot 6.1^{\circ}$. In addition, the PXRD pattern for Chen's octahedral complex has an isolated diffraction peak at a $2 \theta$ value of $c a .26 \cdot 5^{\circ}$.[25] However, in the pattern for the square-pyramidal complex, an isolated diffraction peak at this $2 \theta$ value is not observed and instead a cluster of peaks 
are seen, with a sharp reflection at a $2 \theta$ value of $c a .29^{\circ} .[25]$ Herein, we see that the simulated pattern does not contain any significant diffraction between a $2 \theta$ value of 25 $30^{\circ},[21]$ however the ball mill product does show an intense peak at a $2 \theta$ value of $c a .26^{\circ}$. Furthermore, Chen et al.[25] do not report any significant differences between the IR spectra of the two compounds, in-line with our experimental observations.

\author{
Although with the available data we cannot fully confirm the amount of DMF coordinated \\ to $\mathrm{Cu}(\mathrm{II})$, comparisons with the literature and the information from the Crystal Structure \\ Database (CSD), as discussed above, allows us to conclude that an octahedral complex \\ of formula $\left[\mathrm{Cu}(\mathrm{HMel})_{2}(\mathrm{DMF})_{x}\right]$ (where $x=2$ ), is the most likely product formed by ball \\ milling, instead of the expected square-pyramidal complex.[21] Additionally, we \\ strengthen our argument for obtaining an octahedral complex later, when we discuss the \\ preparation of $\left[\mathrm{Cu}(\mathrm{HMel})_{2}(\mathrm{THF})_{2}\right] \cdot[26]$
}


On account of the possible application of $\left[\mathrm{Cu}(\mathrm{HMel})_{2}(\mathrm{DMF})_{\curlywedge}\right]$ as a chemotherapeutic NSAID, it is important to reduce the general toxicity (i.e. toxicity targeted towards all cells, not just cancer cells) of the complex. This could be achieved by replacing DMF with more innocuous solvents.[27] Therefore, the Liquid Assisted Grinding (LAG)[28] of $\left(\mathrm{Cu}(\mathrm{OAc})_{2} \cdot \mathrm{H}_{2} \mathrm{O}\right)$ and $\mathrm{H}_{2}$ Mel was carried out at $15 \mathrm{~Hz}$ for $2 \mathrm{hrs}$ (to ensure a complete reaction), in a 2:2.2 mol. eq. mixture of $\mathrm{EtOH}: \mathrm{S}$, where $S$ is acetonitrile (MeCN), tetrahydrofuran (THF), dimethyl sulfoxide (DMSO) or $\mathrm{H}_{2} \mathrm{O}$. PXRD showed that regardless of the solvent used, the $2 \theta$ peak positions were largely similar in all cases (Figure 5), although some small variations were observed, associated with differences in the crystal \begin{tabular}{l|l} 
packing & because of the various solvents employed.
\end{tabular}

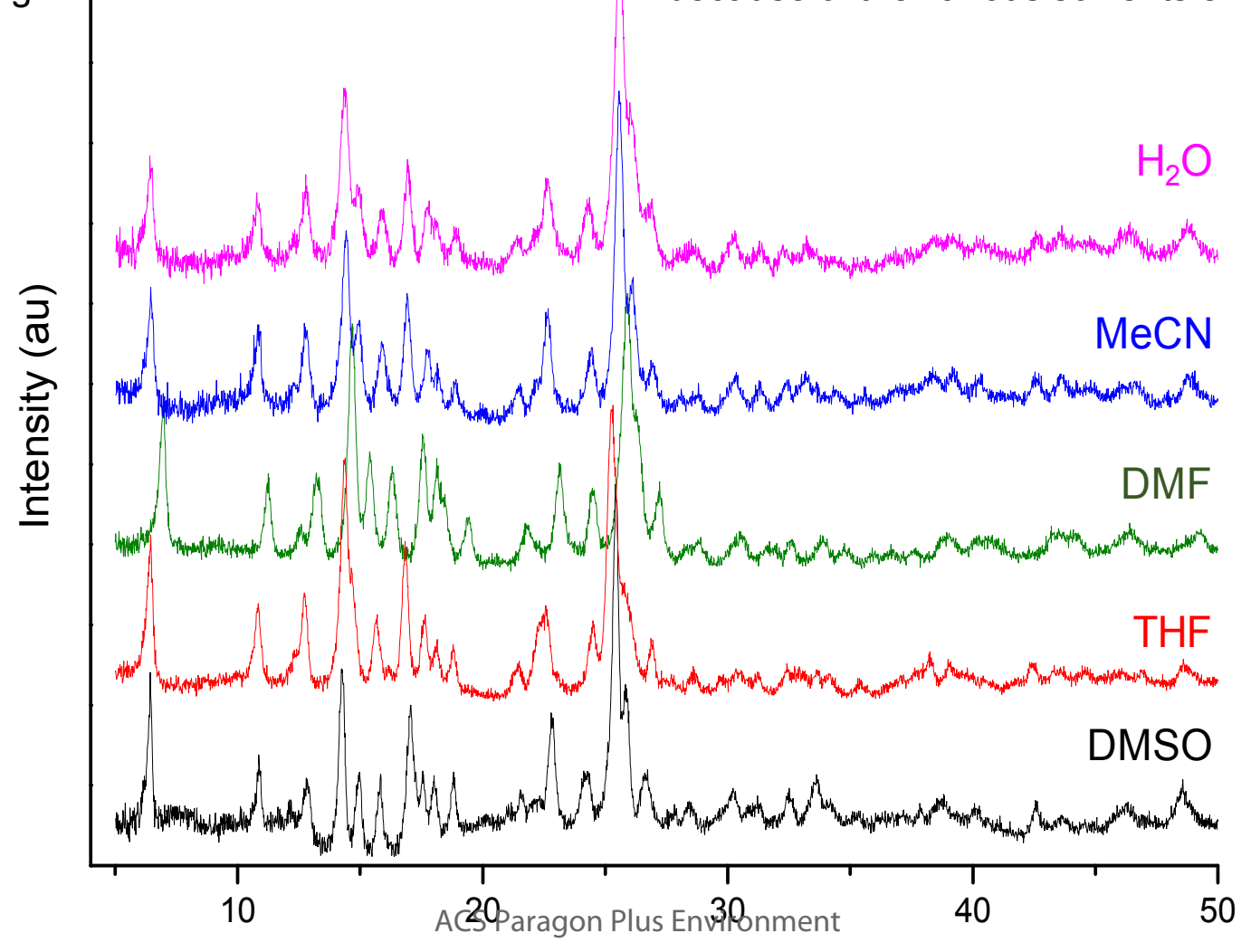


Figure 5. PXRD patterns of $\mathrm{Cu}(\mathrm{II})$ meloxicam complexes $\left[\mathrm{Cu}(\mathrm{HMel})_{2}(\mathrm{~S})_{\mathrm{x}}\right]$ obtained upon varying the coordinating solvent, $\mathrm{S}$, and milling at $15 \mathrm{~Hz}$ for $2 \mathrm{hrs}$.

Whilst most of these compounds have not previously been reported, $\left[\mathrm{Cu}(\mathrm{HMel})_{2}(\mathrm{THF})_{2}\right]$ has been shown to have an octahedral geometry[26] and the synthesis of $\left[\mathrm{Cu}(\mathrm{HMel})_{2}\left(\mathrm{H}_{2} \mathrm{O}\right)_{2}\right]$ has also been reported.[23] Crucially, the simulated PXRD pattern of $\left[\mathrm{Cu}(\mathrm{HMel})_{2}(\mathrm{THF})_{2}\right]$ and that obtained from the ball mill experiment matched well (see ESI, Figure S17). Furthermore, the PXRD patterns obtained for all the complexes, whereby 
the solvent (S) was varied, were very similar, further supporting that synthesis by ball milling results in the formation of an octahedral complex, rather than square-pyramidal. This is a very interesting result, highlighting the advantage that mechanochemical synthesis can result in different compounds or phases, compared to those obtained in solution.

Importantly, the coordinated-solvent study shows that DMF, which is toxic to all cells, is not essential for the successful mechanochemical synthesis of a $\mathrm{Cu}(\mathrm{II})$ meloxicam complex.

The potency of mechanochemically prepared $\left[\mathrm{Cu}(\mathrm{HMel})_{2}(\mathrm{~S})_{\chi}\right]$, where $\mathrm{S}=\mathrm{DMF}, \mathrm{DMSO}$ or $\mathrm{H}_{2} \mathrm{O}$, was assessed by Resazurin cell viability assay. Coordination of DMSO may enhance the anti-proliferative effects of $\left[\mathrm{Cu}(\mathrm{HMel})_{2}(\mathrm{~S})_{x}\right]$, on account of the high affinity which DMSO has for cancer-causing, free-radical species. In addition, the ability of DMSO to permeabilise membranes, including the blood-brain barrier, may improve the targeted activity of the $\mathrm{Cu}$ (II)-NSAID complex towards various forms of brain cancer.[29] As $\mathrm{H}_{2} \mathrm{O}$ 
has been demonstrated to be less toxic to both healthy and cancer cells (compared with the other coordinating solvents investigated),[27] $\left[\mathrm{Cu}(\mathrm{HMel})_{2}\left(\mathrm{H}_{2} \mathrm{O}\right)_{x}\right]$ was selected for testing. In addition, $\left(\left[\mathrm{Cu}(\mathrm{HMel})_{2}(\mathrm{DMF})\right] \cdot 0.25 \mathrm{H}_{2} \mathrm{O}\right)$ prepared conventionally, was tested and employed as a benchmark for the ball mill products.

IGROV-1 and SKOV-3 ovarian cancer cell lines were initially incubated with $10-100 \mu \mathrm{M}$ of $\left(\left[\mathrm{Cu}(\mathrm{HMel})_{2}(\mathrm{DMF})\right] \cdot 0.25 \mathrm{H}_{2} \mathrm{O}\right)$ (prepared via conventional synthesis), where the final DMSO concentration $(<2 \%)$ did not contribute to the overall toxicity. The cell viability was then measured after 48 and 72 hrs, with greater potency observed for SKOV-3 cells (see ESI, Figure S18), in line with that reported by Cini et al.[21] for $\left[\mathrm{Cu}(\mathrm{HPir})_{2}(\mathrm{DMF})_{2}\right]$. Furthermore, it was determined that dramatic cell death occurred within the first $48 \mathrm{hrs}$ at $100 \mu \mathrm{M}$. Subsequently, the toxicity of $\mathrm{Cu}(\mathrm{II})$ complexes obtained by ball milling, as well as the uncoordinated ligand, were tested in SKOV-3 cancer cells. 48 hrs post-incubation, the $\mathrm{Cu}(\mathrm{II})$ complex toxicity was concentration-dependent (from $10-100 \mu \mathrm{M}$ ). As the concentration of the uncoordinated ligand increased (from 50 to $100 \mu \mathrm{M}$ ), there was a 
very small decrease in cell viability, ca. $5-10 \%$, however, this drop in cell viability was too small for it to be considered as cytotoxic (Figure 6). 


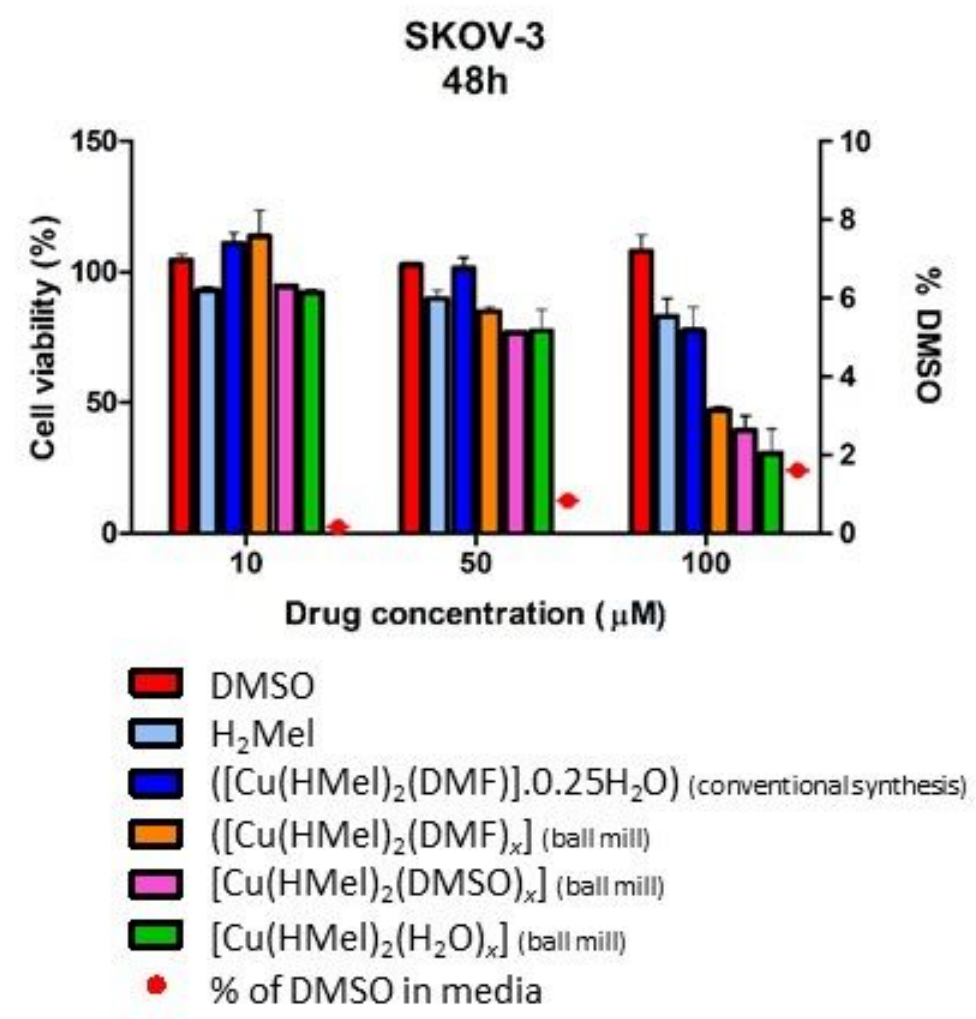

Figure 6. Cytotoxicity of various $\left[\mathrm{Cu}(\mathrm{HMel})_{2}(\mathrm{~S})_{\times}\right]$complexes. SKOV-3 cells were seeded in 96-well plates (1x104 cells/well), and next day incubated with different drug concentrations (10, 50 and $100 \mu \mathrm{M})$. Cell viability was assessed using Resazurin assay.

The results are expressed as the mean \pm SD of $n=6$ samples of two independent experiments, calculated as a percentage of the control.

Upon closer analysis of the cytotoxic behaviour of the $\mathrm{Cu}(\mathrm{II})$ complexes, no significant decrease in cell viability can be seen at $10 \mu \mathrm{M}$. Furthermore, there does not appear to be a substantial difference between the cytotoxicity of the parent ligand and the $\mathrm{Cu}(\mathrm{II})$ 
complexes. However, at $50 \mu \mathrm{M}$ we see a decrease in cell viability for the $\mathrm{Cu}(\mathrm{II})$ complexes

of ca. $10-20 \%$, whilst at $100 \mu \mathrm{M}$, the cytotoxicity of all $\mathrm{Cu}(\mathrm{II})$ complexes significantly

improved, with $>50 \%$ cell death being observed. Interestingly however, there was one

exception, $\left(\left[\mathrm{Cu}(\mathrm{HMel})_{2}(\mathrm{DMF})\right] \cdot 0.25 \mathrm{H}_{2} \mathrm{O}\right)$ prepared via conventional synthesis, showed

only ca. $20 \%$ cell death at $100 \mu \mathrm{M}$, but importantly, this is still regarded as cytotoxic. It

must also be noted that the treatments at a concentration of $100 \mu \mathrm{M}$ (and the ball mill

products at $50 \mu \mathrm{M})$ had a significance difference compared to the control and versus the

conventional method of synthesis (see ESI Figure S19 for complete ANOVA analysis).

Unexpectedly, the ball mill product, $\left[\mathrm{Cu}(\mathrm{HMel})_{2}(\mathrm{DMF})_{x}\right]$, exhibited enhanced cytotoxic behaviour (ca. $30-40 \%$ ), compared with that conventionally synthesised, on SKOV-3 cells, $48 \mathrm{hrs}$ after treatment at $100 \mu \mathrm{M}$.

It must also be noted that the studies carried out here and those of Cini[21] and Alexandrov,[23] all agree that the $\mathrm{Cu}(\mathrm{II})$ complexes exhibited enhanced cytotoxicity, 


\begin{abstract}
compared to the uncoordinated ligand. This is most probably due to the enhanced efficacy
that tumour cells have for metal complexes or the positive redox potential offered by copper.[18]
\end{abstract}

Although direct comparisons with the literature are difficult due to the different methodologies used, some conclusions can be drawn regarding the cell viability of products produced by ball milling, compared with those synthesised conventionally. For example, in comparison with the study by Cini et al.[21] on the effect of [Cu(HPir $\left.)_{2}(\mathrm{DMF})_{2}\right]$ on SKOV-3 cells, we can conclude that the $\mathrm{H}_{2} \mathrm{Pir}$ derivative is five times more potent than its $\mathrm{H}_{2} \mathrm{Mel}$ analogue. Within $48 \mathrm{hrs}$, [Cu(HPir $\left.)_{2}(\mathrm{DMF})_{2}\right]$ exhibited a $\mathrm{Gl} 50$ value of $20.0 \mu \mathrm{M}$, i.e., $50 \%$ cancer cell death is achieved within this time. In order for $\left(\left[\mathrm{Cu}(\mathrm{HMel})_{2}(\mathrm{DMF})_{x}\right]\right.$ to reach a cell viability of $c a .50 \%$ within $48 \mathrm{hrs}, 100 \mu \mathrm{M}$ concentrations were required. However, $\left(\left[\mathrm{Cu}(\mathrm{HMel})_{2}(\mathrm{DMF})_{x}\right]\right.$ has a greater potency towards SKOV-3 cancer cells than $\left[\mathrm{Cu}(\mathrm{HMel})_{2}\left(\mathrm{H}_{2} \mathrm{O}\right)_{2}\right]$ towards HeLA cells (cervical cancer cell lines), as reported by Alexandrov et al..[23] Expressing our concentrations in the same units as these authors, 
we observe $>50 \%$ SKOV-3 cell death within $48 \mathrm{hrs}$, using a concentration of ca. 90 $\mu \mathrm{g} / \mathrm{mL}$. In order to obtain a similar cell viability result, HeLa cell lines would have to be treated with $500 \mu \mathrm{g} / \mathrm{mL}$ solutions of $\left[\mathrm{Cu}(\mathrm{HMel})_{2}\left(\mathrm{H}_{2} \mathrm{O}\right)_{2}\right]$ over $96 \mathrm{hrs}$.

It is possible that the enhanced cytotoxicity of $\left[\mathrm{Cu}(\mathrm{HMel})_{2}(\mathrm{DMF})_{\chi}\right]$ prepared viaball milling, is a direct result of having two DMF molecules per one $\mathrm{Cu}(\mathrm{II})$ coordination site, as DMF is known to be cytotoxic in itself.[29] However, the difference in cytotoxicity between the ball mill and conventionally prepared complexes (ca. $30-40 \%$ ) appears to be too significant to be the result of additional DMF alone.[29] Whilst further investigation is needed to determine the exact cause for this enhanced cytotoxicity, several factors may be taken into consideration. For example, it is known that relatively small variations in the coordination environment of $\mathrm{Cu}(\mathrm{I}) / \mathrm{Cu}(\mathrm{II})$ complexes can have a significant effect on their anticancer activity; e.g. the nature of the anion $\left(\mathrm{X}^{-}\right)$has been reported to affect the cytotoxicity of $\left[\mathrm{Cu}\left\{\mathrm{NH}(\mathrm{R})-\left(\mathrm{CH}_{2}\right)_{n}-\mathrm{NH}_{2}\right\} \mathrm{LX}\right]^{+}\left(\mathrm{X}=\mathrm{Cl}^{-}, \mathrm{Br}-\right),[30]$ although the reasons for this are unclear. In other cases, similar effects have been related to alterations in the 
$\mathrm{Cu}(\mathrm{II}) / \mathrm{Cu}(\mathrm{I})$ redox potential, which in turn affects the DNA binding and cleavage properties

of the complex.[31] More significantly, it has been reported that octahedral $\mathrm{Cu}(\mathrm{II})$

complexes show enhanced anticancer activity compared to their square-pyramidal analogues.[32] Palaniandavar et al.[32a] found a DNA binding constant up to thirty times

higher for their octahedral complex compared to the square-pyramidal derivative; with increased DNA binding translating to enhanced cytotoxic behaviour.[32b]

\section{CONCLUSION}

In conclusion, we have demonstrated that $\left[\mathrm{Cu}(\mathrm{HMel})_{2}(\mathrm{DMF})_{\rtimes}\right]$ can be successfully prepared by ball milling, under reduced solvent conditions (typically 2 mol. eq. of solvent required). Key to this work, we have shown, for the first time, that $\left[\mathrm{Cu}(\mathrm{HMel})_{2}(\mathrm{DMF})_{x}\right]$ prepared mechanochemically, exhibits similar toxicity towards SKOV-3 cells at $50 \mu \mathrm{M}$ whilst exhibiting enhanced cytotoxicity at $100 \mu \mathrm{M}$. In addition, we have demonstrated that DMF can be replaced with innocuous solvents, which may result in the reduced death of healthy cells, whilst maintaining the chemotherapeutic properties of the complex. It was 


\author{
also confirmed in all cases that the $\mathrm{Cu}(\mathrm{II})$ complexes resulted in greater SKOV-3 cell \\ death than the NSAID, $\mathrm{H}_{2} \mathrm{Mel}$, alone.
}

The higher cytotoxicity found for the copper compounds described herein is an unexpected result that can be related to one or more aspects, as discussed above. Although it is not possible to establish the exact causes with the currently available data, our work highlights the impact that the synthetic method has on the biological response of metal compounds. If more environmentally friendly mechanochemical synthesis is to be implemented by the Pharma industry, it is important to demonstrate that the activity of mechanochemical products remains at least the same as the solvent-based synthesised counterparts, and that the factors that may affect their activity are studied.

Supporting Information. The following file is available free of charge.
Electronic Supplementary Information (PDF): McCalmont et al._ESI 


\title{
Corresponding Author
}

Deborah E. Crawford - School of Chemistry and Biosciences, University of Bradford,

Richmond Road, Bradford, BD7 1DP.

orcid.org/0000-0003-2579-7987

Email: D.Crawford@bradford.ac.uk

\section{Author Contributions}

The manuscript was written through contributions of all authors. All authors have given approval to the final version of the manuscript.

\section{Funding Sources}

We would like to thank the EPSRC for funding (EP/L019655).

\author{
ACKNOWLEDGMENT: We would like to thank Professor Stuart L. James (Queen's \\ University Belfast) for use of the Retsch MM400 mixer ball mill. \\ REFERENCES
}


(1) a) Gomollón-Bel, F., Ten chemical innovations that will change our world: IUPAC identifies emerging technologies in chemistry with potential to make our planet more sustainable. Chem. Int. 2019, 41, 12-17. DOI: 10.1515/ci-2019-0203; b) Do, J. L. and Friščić, T., Mechanochemistry, A Force of Synthesis, ACS Cent. Sci., 2017, 3 (1) 13-19, DOI: 10.1021/acscentsci.6b00277; Tan, D. and García, F., Main group mechanochemistry: from curiosity to established protocols, Chem. Soc. Rev., 2019, 48, 2274-2292, DOI: 10.1039/C7CS00813A; Friščić, T, Mottillo, C and Titi, H. M., Mechanochemistry for Synthesis, Angew. Chem. Int. Ed., 2019, 59 (3) 1018-1029, DOI: 10.1002/anie.201906755.

(2) a) Rodriguez, B.; Bruckmann, A.; Rantanen, T.; Bolm, C., Solvent-Free Carbon-Carbon Bond Formations in Ball Mills. Adv. Synth. Catal. 2007, 349 (14-15), 2213-2233, DOI: 10.1002/adsc.200700252; b) Porcheddu, A., Colacino, E., De Luca, L. and Delogu, F., MetalMediated and Metal-Catalysed Reactions Under Mechanochemical Conditions, ACS Catal., 2020, 10 (15) 8344-8394, DOI: 10.1021/acscatal.0c00142.

(3) Pichon, A.; Lazuen-Garay, A.; James, S. L., Solvent-Free Synthesis of a Microporous MetalOrganic Framework. Crystengcomm 2006, 8 (3), 211-214, DOI: 10.1039/b513750k.

(4) Shang, X. K.; Wang, X. T.; Chen, S. L., Effects of Ball Milling Processing Conditions and Alloy Components on the Synthesis of $\mathrm{Cu}-\mathrm{Nb}$ and Cu-Mo Alloys. Materials 2019, 12 (8), 1224. DOI: $10.3390 / \mathrm{ma1} 2081224$.

(5) a) Kaupp, G.; Naimi-Jamal, M. R.; Schmeyers, J., Solvent-Free Knoevenagel Condensations and Michael Additions in the Solid State and in the Melt with Quantitative Yield. Tetrahedron 2003, 59 (21), 3753-3760, DOI: 10.1016/s0040-4020(03)00554-4; b) Howard, J. L., Cao, Q. and Browne, D. L., Chem. Sci., 2018, 9, 3080-3094, DOI: 10.1039/c7sc05371a.

(6) a) Burmeister, C. F.; Stolle, A.; Schmidt, R.; Jacob, K.; Breitung-Faes, S.; Kwade, A., Experimental and Computational Investigation of Knoevenagel Condensation in Planetary Ball Mills. Chem. Eng. Technol. 2014, 37 (5), 857-864, DOI: 10.1002/ceat.201300738; b) Palazon, F., El Ajjouri, Y. and Bolink, H. J., Making by Grinding: Mechanochemistry Boosts the Development of Halide Perovskites and Other Multinary Metal Halides, Adv. Energy Mater., 2020, 10 (13), 113, DOI: 10.1002/aenm.201902499; He, X., Deng, Y., Zhang, Y., He, Q., Xiao, D., Peng, M., Zhao, Y., Zhang, H., Luo, R., Gan, T., Ji, H. and Ma, D., Cell Reports Physical Science, 2020, 1, 1-12, DOI: 10.1016/j.xrcp.2019.100004.

(7) Crawford, D.; Casaban, J.; Haydon, R.; Giri, N.; McNally, T.; James, S. L., Synthesis by Extrusion: Continuous, Large-Scale Preparation of Mofs Using Little or No Solvent. Chem. Sci. 2015, 6 (3), 1645-1649, DOI: 10.1039/c4sc03217a; Crawford, D. E.; Miskimmin, C. K. G.; Albadarin, A. B.; Walker, G.; James, S. L., Organic Synthesis by Twin Screw Extrusion (TSE): Continuous, Scalable and Solvent-Free. Green Chem. 2017, 19 (6), 1507-1518, DOI: 10.1039/c6gc03413f. 
(8) Martin, C., Twin Screw Extruders as Continuous Mixers for Thermal Processing: A Technical and Historical Perspective. AAPS PharmSciTech 2016, 17 (1), 3-19, DOI: 10.1208/s12249-016-0485-3.

(9) a) André, V., Hardeman, A., Halasz, I., Stein, R. S., Jackson, G. J., Reid, D. G., Duer, M. J., Curfs, C., Duarte, M. T. and Friščić, T., Mechanosynthesis of the Metallodrug Bismuth Subsalicylate from $\mathrm{Bi}_{2} \mathrm{O}_{3}$ and Structure of Bismuth Salicylate without Auxiliary Organic Ligands, Angew. Chem. Int. Ed., 2011, 50 (34), 7858-7861, DOI: 10.1002/anie.201103171, b) Souza, M. S., Diniz, L. F., Vogt, L., Carvalho Jr., P. S., D’vries, R. F. and Ellena, J., Mechanochemical Synthesis of a Multicomponent Solid Form: The Case of 5-Fluorocytosine Isoniazid Codrug, Cryst. Growth Des., 2018, 18 (9), 5202-5209, DOI: 10.1021/acs.cgd.8b00647.

(10) Štrukil, V., Mechanochemical Synthesis of thioureas, ureas and guanidines, Beilstein J. Org. Chem., 2017, 13, 1828-1849, DOI: 10.3762/bjoc.13.178.

(11) Crawford, D. E., Porcheddu, A., McCalmont, A. S., Delogu, F., James, S. L. and Colacino, E., Solvent-free, Continuous Synthesis of Hydrazone-Based Active Pharmaceutical Ingredients by Twin-Screw Extrusion, ACS Sustainable Chem. Eng., 2020, 8 (32), 1223.-12238, DOI: 10.1021/acssuschemeng.0c03816.

(12) Beillard, A., Quintin, F., Gatignol, J., Retailleau, P., Renaud, J., Gaillard, S., Métro, T., Lamaty, F. and Bantreil X., Solving the challenging synthesis of highly cytotoxic silver complexes bearing sterically hindered NHC ligands with mechanochemistry, Dalton Trans., 2020, Advance Article, DOI: 10.1039/D0DT00410C.

(13) Greenblatt, D. J., Elimination Half-Life of Drugs, Ann. Rev. Med., 1985, 36, 421-427, DOI: 10.1146/annurev.me.36.020185.00225.

(14) Prausnitz, M. R. and Langer, R., Transdermal drug delivery, Nat. Biotechnol., 2008, 26 (11), 1261-1268, DOI: 10.1038/nbt.1504.

(15) Kesisoglou, F. and Wu, Y., Understanding the Effect of API Properties on Bioavailability Through Absorption Modeling, AAPS J., 2008, 10 (4), 516-525, DOI: 10.1208/s12248-008-90614.

(16) Mjos, K. D.; Orvig, C., Metallodrugs in Medicinal Inorganic Chemistry. Chem. Rev. 2014, 114 (8), 4540-4563, DOI: 10.1021/cr400460s. 
(17) Petanidis, S.; Kioseoglou, E.; Salifoglou, A., Metallodrugs in Targeted Cancer Therapeutics: Aiming at Chemoresistance-Related Patterns and Immunosuppressive Tumor Networks. Curr. Med. Chem. 2019, 26 (4), 607-623, DOI: 10.2174/0929867324666171116125908.

(18) Denoyer, D.; Masaldan, S.; La Fontaine, S.; Cater, M. A., Targeting Copper in Cancer Therapy: 'Copper That Cancer'. Metallomics 2015, 7 (11), 1459-1476, DOI: 10.1039/c5mt00149h.

(19) (a) IVS Annual; MIMS Publishing: Crows Nest, NSW, Sydney, 1997; pp 145, 276; (b) Furlow, T. W.; Hallenbeck, J. M., Indomethacin Prevents Impaired Perfusion of Dogs Brain after Global Ischemia. Stroke 1978, 9 (6), 591-594, DOI: 10.1161/01.str.9.6.591.

(20) Cini, R.; Giorgi, G.; Cinquantini, A.; Rossi, C.; Sabat, M., Metal-Complexes of the Antiinflammatory Drug Piroxicam. Inorg. Chem. 1990, 29 (26), 5197-5200, DOI: 10.1021/ic00351a012.

(21) Cini, R.; Tamasi, G.; Defazio, S.; Hursthouse, M. B., Unusual Coordinating Behavior by Three Non-Steroidal Anti-Inflammatory Drugs from the Oxicam Family Towards Copper(II). Synthesis, X-Ray Structure for Copper(II)-Isoxicam, -Meloxicam and -Cinnoxicam-Derivative Complexes, and Cytotoxic Activity for a Copper(II)-Piroxicam Complex. J. Inorg. Biochem. 2007, 101 (8), 1140-1152, DOI: 10.1016/j.jinorgbio.2007.04.015

(22) Roy, S.; Banerjee, R.; Sarkar, M., Direct Binding of Cu(II)-Complexes of Oxicam NSAIDs with DNA Backbone. J. Inorg. Biochem. 2006, 100 (8), 1320-1331, DOI: 10.1016/j.jinorgbio.2006.03.006.

(23) Dyakova, L.; Culita, D. C.; Zhivkova, T.; Georgieva, M.; Kalfin, R.; Miloshev, G.; Alexandrov, M.; Marinescu, G.; Patron, L.; Alexandrova, R., 3d Metal Complexes with Meloxicam as Therapeutic Agents in the Fight against Human Glioblastoma Multiforme and Cervical Carcinoma. Biotechnol. Biotechnol. Equip. 2015, 29 (6), 1190-1200, DOI: 10.1080/13102818.2015.1074873.

(24) Tamasi, G. Metal-Oxicam Coordination Compounds: Structure, Biological Activity and Strategies for Administration. Open Crystal. Journ. 2010, 3(2), 41-53, DOI: 10.2174/1874846501003020041.

(25) Jiang, L. T.; Chang, X.; Chen, S. C.; Feng, X. J.; Chen, Q., Supramolecular Assembly of Two Copper(II) Coordination Compounds of Topiroxostat with Dialkylformamide Ligands. Z.Naturforsch.(B) 2019, 74 (6), 479-484, DOI: 10.1515/znb-2019-0011. 
(26) Sanatkar, T. H.; Hadadzadeh, H.; Jannesari, Z.; Khayamian, T.; Ebrahimi, M.; Rudbari, H. A.; Torkzadeh-Mahani, M.; Anjomshoa, M., Characterization, Photocleavage, Molecular Modeling, and DNA- and Bsa-Binding Studies of $\mathrm{Cu}(\mathrm{II})$ and $\mathrm{Ni}$ (II) Complexes with the NonSteroidal Anti-Inflammatory Drug Meloxicam. Inorg. Chim. Acta 2014, 423, 256-272, DOI: 10.1016/j.ica.2014.08.060.

(27) Jamalzadeh, L.; Ghafoori, H.; Sariri, R.; Rabuti, H.; Nasirzade, J.; Hasani, H.; Aghamaali, M.R., Cytotoxic Effects of Some Common Organic Solvents on MCF-7, RAW-264.7 and Human Umbilical Vein Endothelial Cells. Avicenna J Med Biochem. 2016, 4(1), e33453, DOI: 10.17795/ajmb-33453.

(28) Cruz-Cabeza, A. J., Karki, S., Fábián, L., Friščić, T., Day, G. M. and Jones, W., Predicting stoichiometry and structure of solvates, Chem. Commun., 2010, 46, 2224-2226, DOI: 10.1039/B922955H.

(29) Serfontein, W., Cancer Diagnosed: What Now?; Xlibris: Indiana, 2011.

(30) Emam, S. M.; El Sayed, I. E. T.; Nassar, N., Transition Metal Complexes of Neocryptolepine Analogues. Part I: Synthesis, Spectroscopic Characterization, and in Vitro Anticancer Activity of Copper(II) Complexes. Spectroc. Acta Pt. A-Molec. Biomolec. Spectr. 2015, 138, 942-953, DOI: 10.1016/j.saa.2014.03.114.

(31) Rajendiran, V.; Karthik, R.; Palaniandavar, M.; Stoeckli-Evans, H.; Periasamy, V. S.; Akbarsha, M. A.; Srinag, B. S.; Krishnamurthy, H., Mixed-Ligand Copper(II)-Phenolate Complexes: Effect of Coligand on Enhanced DNA and Protein Binding, DNA Cleavage, and Anticancer Activity. Inorg. Chem. 2007, 46 (20), 8208-8221, DOI: 10.1021/ic700755p.

(32) (a) Sharma, M.; Ganeshpandian, M.; Majumder, M.; Tamilarasan, A.; Sharma, M.; Mukhopadhyay, R.; Islam, N. S.; Palaniandavar, M., Octahedral Copper(II)-Diimine Complexes of Triethylenetetramine: Effect of Stereochemical Fluxionality and Ligand Hydrophobicity on $\mathrm{Cu}^{\mathrm{II}} / \mathrm{Cu}^{\mathrm{I}}$ Redox, DNA Binding and Cleavage, Cytotoxicity and Apoptosis-Inducing Ability. Dalton Transactions 2020, 49 (24), 8282-8297, DOI: 10.1039/d0dt00928h; (b) Manikandamathavan, V. M.; Parameswari, R. P.; Weyhermuller, T.; Vasanthi, H. R.; Nair, B. U., Cytotoxic Copper (II) Mixed Ligand Complexes: Crystal Structure and DNA Cleavage Activity. Eur. J. Med. Chem. 2011, 46 (9), 4537-4547, DOI: 10.1016/j.ejmech.2011.07.030. 


\section{Graphical Abstract:}

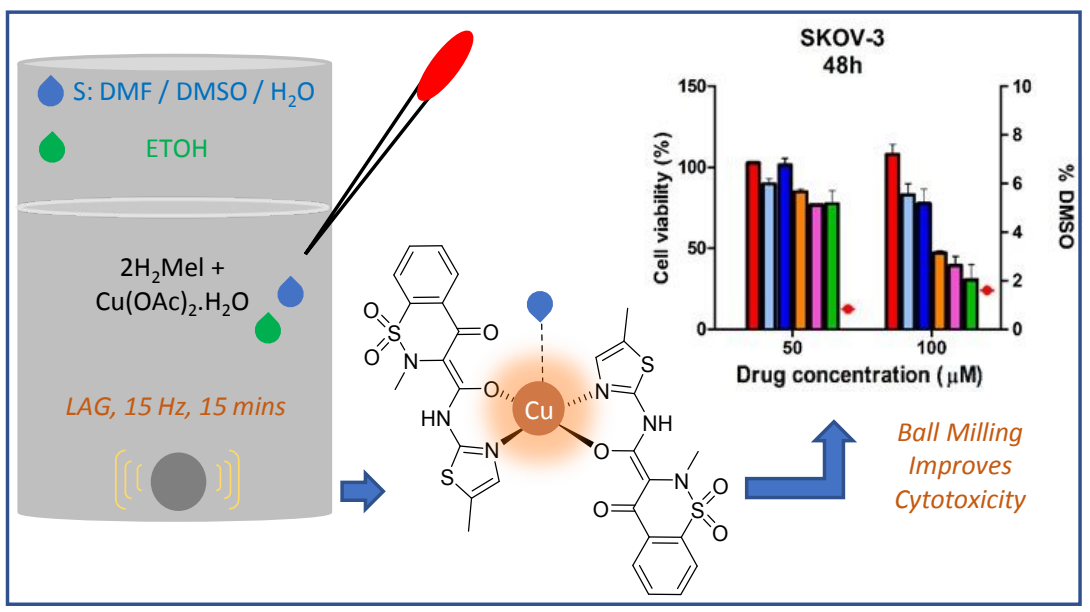

SYNOPSIS: The enhanced cytotoxicity afforded by ball mill synthesis under minimal solvent conditions, is shown for a $\mathrm{Cu}(\mathrm{II})$ metallodrug of non-typical geometry. 


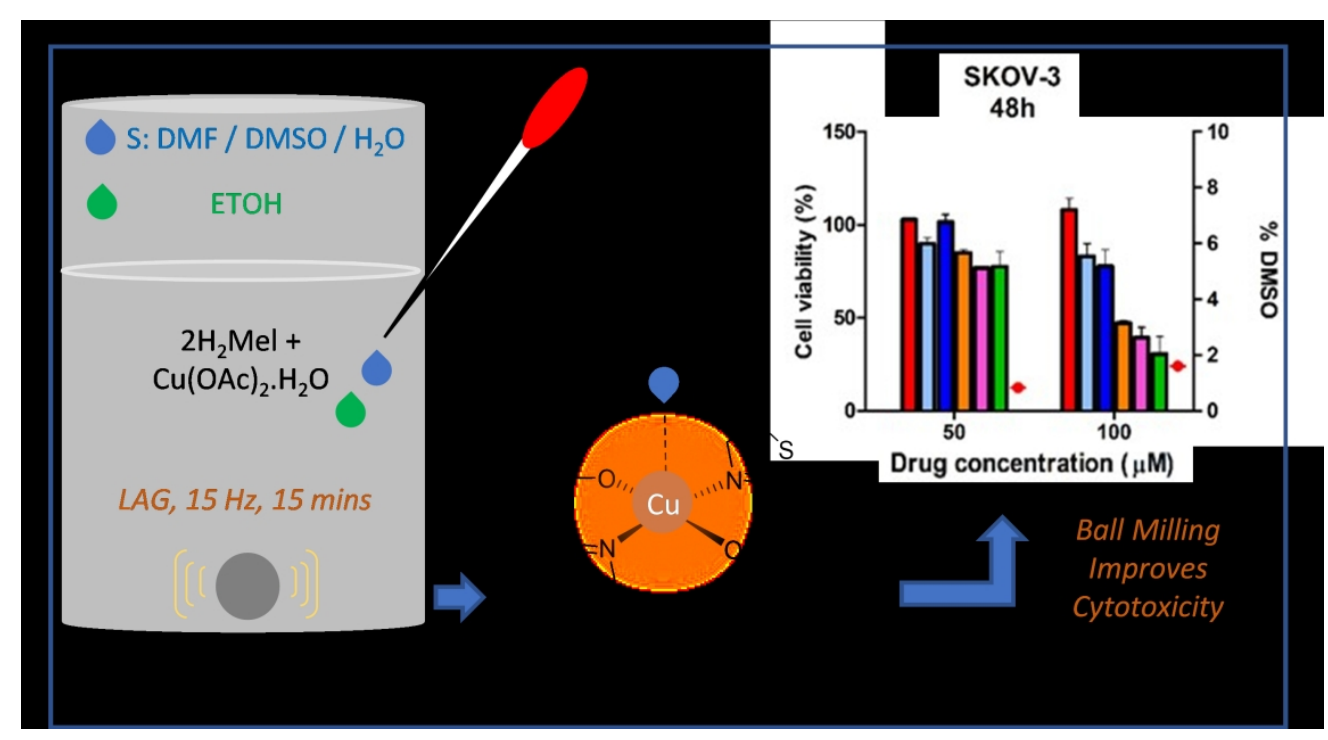

$574 \times 313 \mathrm{~mm}(120 \times 120$ DPI $)$ 